\title{
Neuropeptide Y Receptor Type 1
}

National Cancer Institute

\section{Source}

National Cancer Institute. Neuropeptide Y Receptor Type 1. NCI Thesaurus. Code C105406.

Neuropeptide $Y$ receptor type 1 (384 aa, $\sim 44 \mathrm{kDa}$ ) is encoded by the human NPY1R gene. This protein is involved in diverse physiological functions as a receptor for neuropeptide $Y$. 